\title{
Optimization in handling tasks in monorail transportation system at Busan port
}

\author{
Long Le Ngoc Bao ${ }^{1}$, Duy Anh Nguyen ${ }^{1}{ }^{*}$, Hwan-seong Kim ${ }^{2}$
}

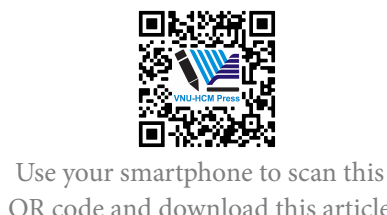

QR code and download this article
${ }^{1}$ Ho Chi Minh City University of

Technology, VNU-HCM, Vietnam

${ }^{2}$ Korea Maritime and Ocean University, Busan, South Korea

Correspondence

Duy Anh Nguyen. Ho Chi Minh City University of Technology, VNU-HCM, Vietnam

Email: duyanhnguyen@hcmut.edu.vn

History

- Received: 08-06-2020

- Accepted: 22-03-2021

- Published: 31-03-2021

DOI : 10.32508/stdjet.v4i1.746

\section{Check for updates}

\section{Copyright}

(C) VNU-HCM Press. This is an openaccess article distributed under the terms of the Creative Commons Attribution 4.0 International license.

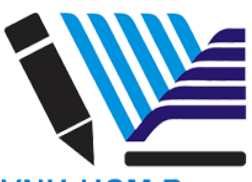

\section{ABSTRACT}

This paper presents an optimal solution for handling tasks at Busan Container Port in South Korea. Currently, there is a monorail transportation system under construction that supposed to be ready in use in 2045. This is the project in association with Korean Government that aims to increase the utility rate at Busan Port - one of the biggest container port in the world. In new system, transport vehicles called shuttles would move on the rail in only one direction through changestations - which are similar to the lane driver systems on the railway - to reach designated terminals where loaders are waiting to handle. The whole operation can be divided into two main procedures: scheduling tasks and assigning tasks. All containers must be first planned properly at each terminal using the task table, and then must be assigned optimally to the shuttles to achieve the best result. The paper mainly focuses on time optimization in scheduling tasks and assigning tasks - critical optimization problems in reducing working time and average delay for the whole system. To resolve, a heuristic algorithm called Greedy Algorithm is implemented to properly schedule tasks and assign arranged tasks to relevant shuttles by calculating the moving time between each terminal and the accessing time from a shuttle to a loader. All important results with and without Greedy Algorithm are recorded and compared in order to point out the differences between the procedures, including the total working time, total moving distance, average moving distance and average delay in the whole process. All simulations are implemented by MATLAB software, where final result charts show the criteria points and highlight the advantage of new transportation system, as well as the benefit of optimization procedures applied.

Key words: Inter Terminal Transport, Monorail System, Scheduling, Assigning, Busan Port, Greedy Algorithm

\section{INTRODUCTION}

The monorail system project at Busan Port is a kind of Inter Terminal Transport (ITT) system motivated by similar transport systems in the world ${ }^{1-4}$. As described in Figure $1^{5}$, an ITT system is an integrated transport system that would exploit usage of facilities in container port (container terminals, shipping stations, service stations, transport terminals, valueadded facilities, warehouses and depots ...) in order to maximize port's throughput ${ }^{6,7}$, which might be up to millions of TEUs (Twenty-feet Equivalent Units) each year at major container ports in the world ${ }^{8}$.

About simulation and optimization approaches for ITT system, many studies have been made based on the model of Port of Rotterdam (Maasvlakte I \& II Project ${ }^{9,10}$ ), since it is the largest container port in Europe with many transport modes (railway, roadway, seaway) and vehicle types (MTS, AGV, ALV, barge, vessel, train... $)^{10}$. According to Leonard and Stefan $\left(2017^{11}\right)$, research approaches could be classified into simulation approaches, optimization approaches and information system approaches, which mainly focus on transport scheduling, vehicle routing and information technologies. This paper would concentrate on task scheduling for loaders and task assigning for shuttles by applying $A^{\star}$ Algorithm (described later in Methodology Section), as referred to Qiu et al. $\left(2002^{12}\right)$ and $\mathrm{Ng}\left(2005^{13}\right)$.

The operation scene of the ITT Monorail System in Busan is demonstrated as shown in Figure $2^{14}$. Containers from terminal are moved to loader's position and grabbed onto the prepared shuttle. Prototypes of loader and shuttle are illustrated in Figure $3^{14}$. Since this is a monorail, all shuttles are directed one way only. Some special stations called change stations, laying at two ends of the terminal and acting like lanedrivers on the railway, are responsible to direct the shuttles into other lanes, as described in detail in Figure $4^{14}$. A buffer on the change station (turn zone) allows the shuttles to wait until the lanes change correctly.

Our duty in this project is to analyze the general performance of the monorail system (how shuttles move 


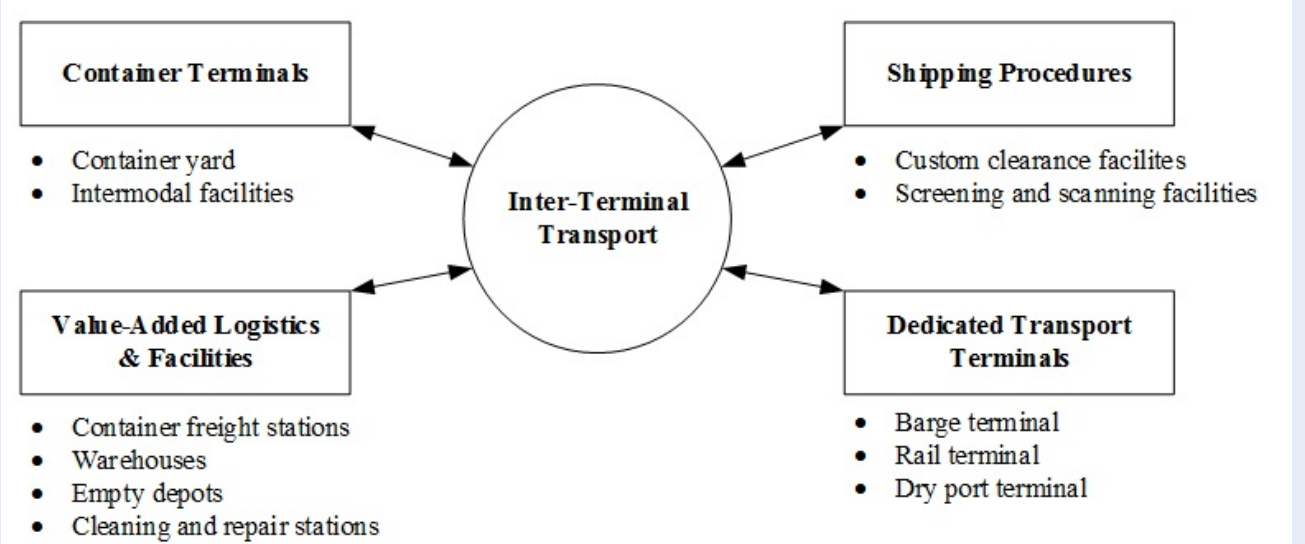

Figure 1: Components of a general ITT system

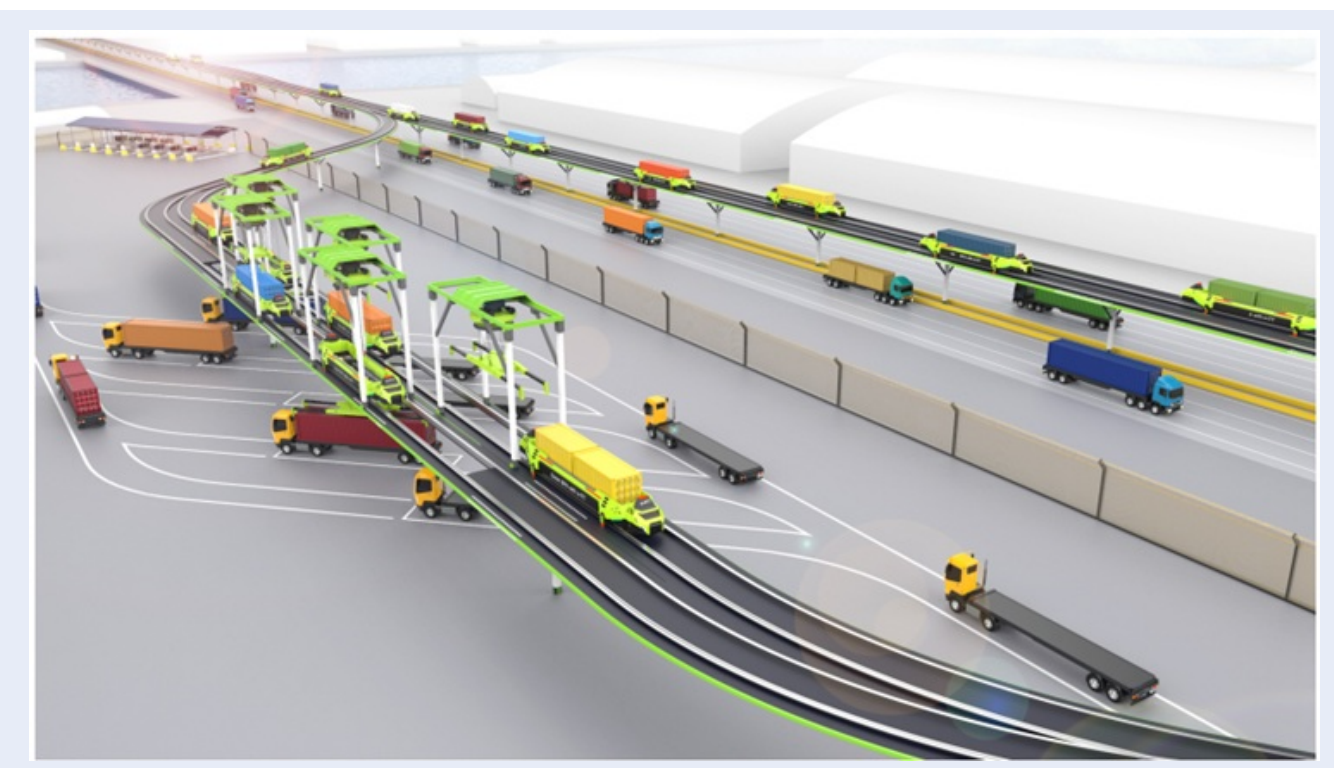

Figure 2: Operation scene of the Monorail System at Busan Port

and handle tasks on the rail and measurement of traffic density on important nodes) in comparison with traditional method and propose optimal solution, by simulating the system's operation with information given by project's managers. In the next Section, we would describe in detail how to optimize two major procedures in operation: task scheduling and task assigning, as well as how to apply heuristics algorithms to resolve these combinatorial problems.

\section{METHODOLOGY}

In this Section, as a part of requirements from the project managers, optimization procedures for task scheduling and task assigning will be explained in de- tail. The task scheduling procedure would describe how given tasks should be arranged at loader's position to optimize the working time, and the task assigning procedure would show how shuttles pick up the arranged tasks in order to lower the total travel distance.

Full layout of the monorail system is modelled by MATLAB as shown in Figure 5, presenting the positions of terminals and change stations as well as measure points ( $Q$ points) on the rail. The change stations marked in green zones locates as two ends of a terminal to help drive the shuttles correctly. Container flows will be tracked at the measure positions marked " $\mathrm{x}$ ". As proposed by the project managers, each termi- 


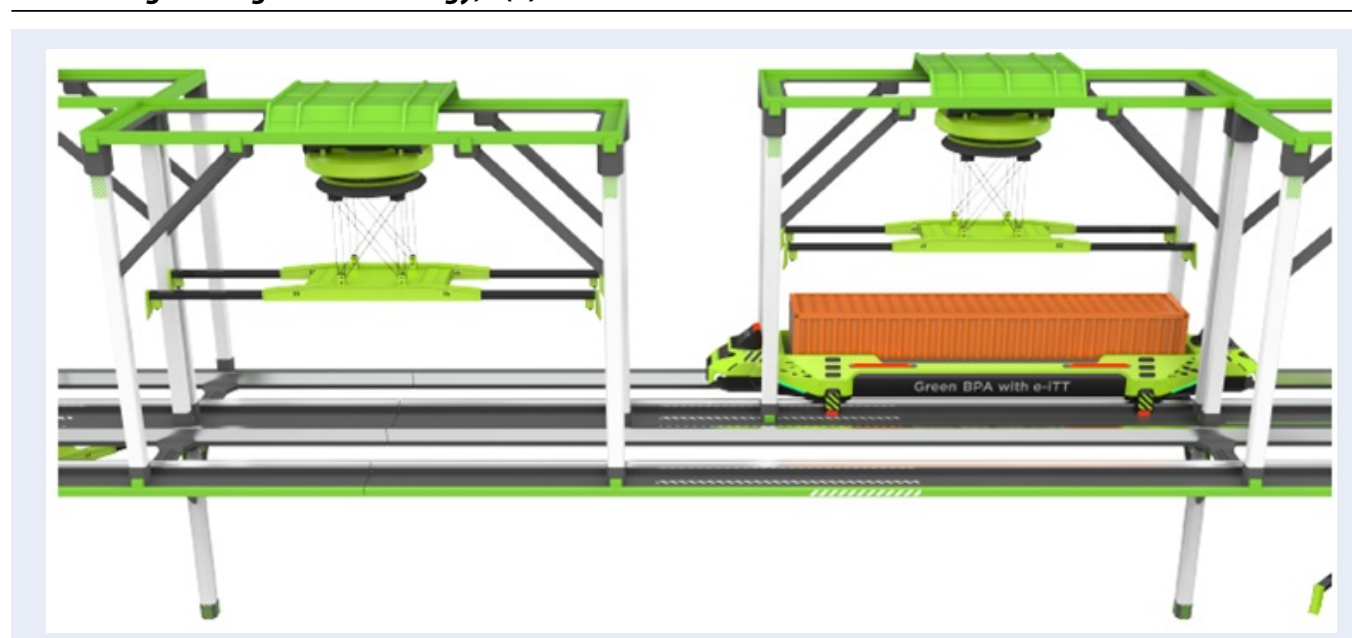

Figure 3: Prototypes of loader and shuttle using in the Monorail System

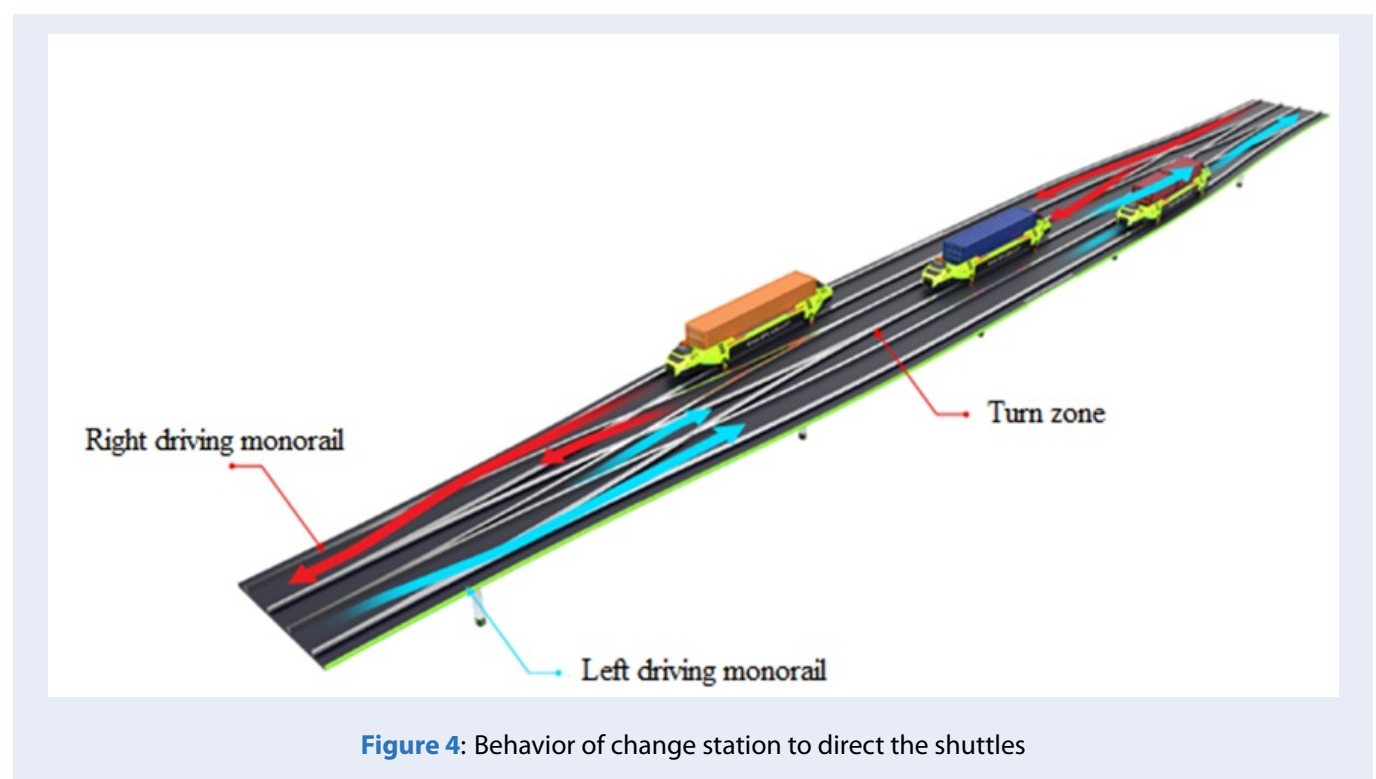

nal requires 2 loaders for handling given tasks, which are mentioned in Table 1.

\section{Assumptions made}

To limit the range for this research, there are some assumptions made for the simulation model, which are referred to the current stage of the project and proposed by the project managers, as following:

- Dynamic specifications of components in the system (real dimensions, weights, energy consumption) are temporarily neglected, because main target of this simulation is to visualize movement of shuttles in general.
- Each loader only grabs one container at one time.

- Each shuttle only carries one container at one time.

- Priority of tasks is identical.

- When being assigned, shuttles will not change their given task until they finish their jobs

- Only available shuttles take the assignment. If there are not any available ones, all requested tasks must wait.

- System is considered ideally, meaning all malfunction cases are ignored.

The next subsections will explain the solution for optimal scheduling and assigning respectively. 


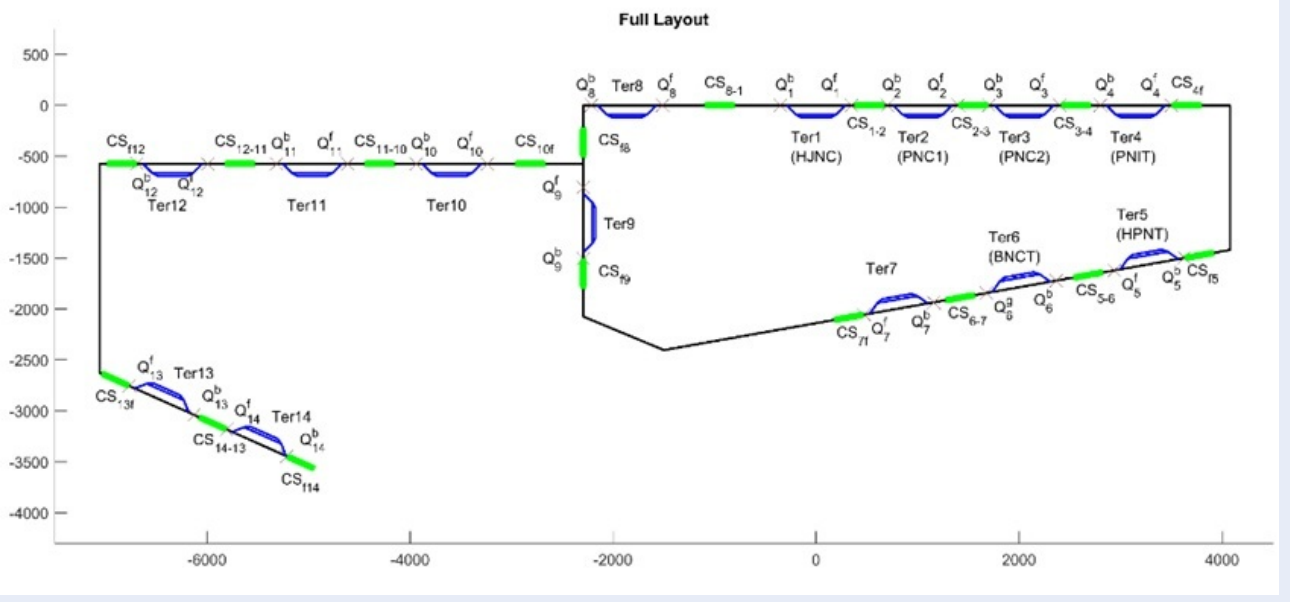

Figure 5: Full layout of new monorail system

\section{Task scheduling}

Since each loader only handle one container at one time, the task scheduling issue becomes: arranging the order of tasks at each loader position. The total handling time of loaders would remain the same, however different orders would result in different delays, depending on the current situation of the handling shuttles.

For clearer explanation, a simple study case is introduced as shown in Table 1, presenting number of containers to be transferred among the terminals, which is actually scaled to real demand. All given tasks will then be labelled with ID numbers (in this case, the ID numbers spread from 1 to 254) and stored in system with necessary detail such as departure, destination, total travel distance and current status (unassigned/ pending/ being carried/ finished). The tasks are labelled from left to right and up to down in this table sequentially. The result after labelling all tasks will look like in Table 2 (unarranged yet). For each terminal, one loader would handle the odd IDs and one loader would handle the even IDs.

After achieving Table 2, the next mission is to arrange all tasks at each loader's position in an optimal sequence by evaluating the distance cost of each task. This is a combinatorial optimization problem that similar to the Travelling Salesman Problem (TSP Problem ${ }^{15-17}$ ) - a classical optimization issue in which a salesman needs to decide a shortest tour to complete all missions. There are many approaches to solve this problem but none guarantees a global solution. In this paper, we suggest to apply Greedy Algorithm ${ }^{18-20}$, as it appears to be the fastest approach with an acceptable extent. The procedure can be summarized as below:

- Step 1: Enumerate all tasks with corresponding loaders in array form.

- Step 2: For every loader, measure distance cost of all handling tasks Dloader.

- Step 3: Sort task IDs in ascending order of Dloader.

- Step 4: Index new task IDs with corresponding distance cost in sorted array Dloader.

- Step 5: Repeat step 2 until all loaders have been scheduled.

Obtained result for task scheduling procedure is expressed as shown in Table 3. Now all loaders have the outgoing tasks scheduled so that the task with lower cycle time will be prioritized to be finished first. It is similar to the principle of TSP where salesman tends to choose the nearest city as the next destination.

\section{Task assigning}

The next issue is to assign the optimal schedule to working shuttles so that the total working time is minimum. As assumed that one shuttle only carries one container at one time, we define:

$$
n=\min (\text { TaskRequired, ShuttleAvailable) }
$$

where TaskRequired is the number of tasks required and ShuttleAvailable is the number of available shuttles at a moment.

The problem now becomes: Pairing $\mathrm{n}$ tasks with $\mathrm{n}$ shuttles so that the $\operatorname{sum} \sum_{n} f$ of function cost $f$ is minimized. In our research, we decide to choose $f$ as the 


\begin{tabular}{|c|c|c|c|c|c|c|c|c|c|c|c|c|c|c|c|}
\hline $\begin{array}{l}\text { From } \\
\text { Ter } \\
\backslash \text { To } \\
\text { Ter }\end{array}$ & $\mathrm{T} 1$ & T2 & T3 & $\mathrm{T} 4$ & T5 & T6 & T7 & T8 & T9 & T10 & T11 & T12 & T13 & T14 & $\begin{array}{l}\text { Total } \\
\text { Ex- } \\
\text { port }\end{array}$ \\
\hline Ter 1 & 0 & 2 & 2 & 2 & 1 & 2 & 2 & 2 & 2 & 2 & 2 & 2 & 2 & 2 & 25 \\
\hline Ter 2 & 1 & 0 & 0 & 1 & 1 & 1 & 1 & 1 & 1 & 2 & 1 & 1 & 1 & 1 & 13 \\
\hline Ter 3 & 1 & 0 & 0 & 1 & 1 & 1 & 1 & 1 & 1 & 2 & 1 & 1 & 1 & 1 & 13 \\
\hline Ter 4 & 2 & 2 & 2 & 0 & 2 & 2 & 2 & 2 & 2 & 3 & 2 & 2 & 2 & 2 & 27 \\
\hline Ter 5 & 2 & 2 & 2 & 2 & 0 & 2 & 2 & 2 & 2 & 2 & 2 & 2 & 2 & 2 & 26 \\
\hline Ter 6 & 2 & 1 & 1 & 1 & 1 & 0 & 2 & 2 & 1 & 2 & 2 & 2 & 2 & 2 & 21 \\
\hline Ter 7 & 2 & 1 & 1 & 1 & 1 & 1 & 0 & 2 & 1 & 2 & 2 & 2 & 2 & 2 & 20 \\
\hline Ter 8 & 2 & 1 & 1 & 1 & 1 & 1 & 2 & 0 & 1 & 2 & 2 & 2 & 2 & 2 & 20 \\
\hline Ter 9 & 1 & 1 & 1 & 1 & 1 & 1 & 2 & 2 & 0 & 1 & 2 & 2 & 1 & 1 & 17 \\
\hline Ter 10 & 1 & 1 & 1 & 1 & 1 & 1 & 2 & 2 & 1 & 0 & 2 & 2 & 1 & 1 & 17 \\
\hline Ter 11 & 1 & 1 & 1 & 1 & 1 & 1 & 2 & 2 & 1 & 1 & 0 & 0 & 1 & 1 & 14 \\
\hline Ter 12 & 1 & 1 & 1 & 1 & 1 & 1 & 1 & 1 & 1 & 2 & 0 & 0 & 1 & 1 & 13 \\
\hline Ter 13 & 1 & 1 & 1 & 1 & 1 & 1 & 1 & 1 & 1 & 2 & 2 & 2 & 0 & 0 & 15 \\
\hline Ter 14 & 1 & 1 & 1 & 1 & 1 & 1 & 1 & 1 & 1 & 2 & 1 & 1 & 0 & 0 & 13 \\
\hline $\begin{array}{l}\text { Total } \\
\text { Im- } \\
\text { port }\end{array}$ & 18 & 15 & 15 & 15 & 14 & 16 & 21 & 21 & 16 & 25 & 21 & 21 & 18 & 18 & 254 \\
\hline
\end{tabular}

Euclidean distance from a shuttle to an incoming task, formulated as below:

$$
f(i, j)=\sqrt{\left(x_{i}-x_{j}\right)^{2}+\left(y_{i}-y_{j}\right)^{2}}
$$

where $\left(\mathrm{x}_{i}, \mathrm{y}_{i}\right)$ and $\left(\mathrm{x}_{j}, \mathrm{y}_{j}\right)$ are position of task $i$ and shuttle $j$ respectively.

From (2), it is realized that the shuttles always aim to reach the nearest task position in order to minimize the travel distance cost. According to Greedy Algorithm, this is supposed to reduce the total working distance of all shuttles. The procedure is summarized in a flowchart as shown in Figure 6 below.

This procedure is built based on the optimal schedule obtained from the task scheduling procedure mentioned previously. For every sampling time, status of all tasks and shuttles are updated to check for the requesting tasks. If there are not any available shuttles nor requesting tasks, the assignment keeps unchanged until the next check. In case there are some, then the required tasks and available shuttles will be listed in a matrix form corresponding to function cost $f(i, j)$. Appling Greedy Algorithm again, smallest values in the matrix would be picked out consecutively until it reaches $n$ elements. The indices of chosen elements express the task IDs and the assigned shuttles. The process continues until all tasks have been addressed and no more tasks in the queue.

Final result of task scheduling and task assigning procedures will be integrated in the simulation in the next Section and their advantages will also be highlighted.

\section{SIMULATION}

In this Section, performance of the monorail system will be simulated using the method described in Section 2. As a requirement of the project, a userinterface program was created by MATLAB R2018 to flexibly test the system's configurations before reality implementation. The final objectives are to verify the advantage of new ITT system and how optimization approaches give impacts to the overall work.

First of all, some assumptions would be declared in order to make the simulation more consistent and informative, as expressed below:

- The simulation uses the task table in Section 2 as the input. 
Table 2: Result before scheduling

\begin{tabular}{|c|c|c|c|c|c|c|c|c|c|c|c|c|c|c|c|}
\hline Ter & Loader & Task & & & & & & & & & & & & & \\
\hline \multirow[t]{2}{*}{1} & 1 & 1 & 3 & 5 & 7 & 9 & 11 & 13 & 15 & 17 & 19 & 21 & 23 & 25 & - \\
\hline & 2 & 2 & 4 & 6 & 8 & 10 & 12 & 14 & 16 & 18 & 20 & 22 & 24 & - & - \\
\hline \multirow[t]{2}{*}{2} & 1 & 26 & 28 & 30 & 32 & 34 & 36 & 38 & - & - & - & - & - & - & - \\
\hline & 2 & 27 & 29 & 31 & 33 & 35 & 37 & - & - & - & - & - & - & - & - \\
\hline \multirow[t]{2}{*}{3} & 1 & 39 & 41 & 43 & 45 & 47 & 49 & 51 & - & - & - & - & - & - & - \\
\hline & 2 & 40 & 42 & 44 & 46 & 48 & 50 & - & - & - & - & - & - & - & - \\
\hline \multirow[t]{2}{*}{4} & 1 & 52 & 54 & 56 & 58 & 60 & 62 & 64 & 66 & 68 & 70 & 72 & 74 & 76 & 78 \\
\hline & 2 & 53 & 55 & 57 & 59 & 61 & 63 & 65 & 67 & 69 & 71 & 73 & 75 & 77 & - \\
\hline \multirow[t]{2}{*}{5} & 1 & 79 & 81 & 83 & 85 & 87 & 89 & 91 & 93 & 95 & 97 & 99 & 101 & 103 & - \\
\hline & 2 & 80 & 82 & 84 & 86 & 88 & 90 & 92 & 94 & 96 & 98 & 100 & 102 & 104 & - \\
\hline \multirow[t]{2}{*}{6} & 1 & 105 & 107 & 109 & 111 & 113 & 115 & 117 & 119 & 121 & 123 & 125 & - & - & - \\
\hline & 2 & 106 & 108 & 110 & 112 & 114 & 116 & 118 & 120 & 122 & 124 & - & - & - & - \\
\hline \multirow[t]{2}{*}{7} & 1 & 126 & 128 & 130 & 132 & 134 & 136 & 138 & 140 & 142 & 144 & - & - & - & - \\
\hline & 2 & 127 & 129 & 131 & 133 & 135 & 137 & 139 & 141 & 143 & 145 & - & - & - & - \\
\hline \multirow[t]{2}{*}{8} & 1 & 146 & 148 & 150 & 152 & 154 & 156 & 158 & 160 & 162 & 164 & - & - & - & - \\
\hline & 2 & 147 & 149 & 151 & 153 & 155 & 157 & 159 & 161 & 163 & 165 & - & - & - & - \\
\hline \multirow[t]{2}{*}{9} & 1 & 166 & 168 & 170 & 172 & 174 & 176 & 178 & 180 & 182 & - & - & - & - & - \\
\hline & 2 & 167 & 169 & 171 & 173 & 175 & 177 & 179 & 181 & - & - & - & - & - & - \\
\hline \multirow[t]{2}{*}{10} & 1 & 183 & 185 & 187 & 189 & 191 & 193 & 195 & 197 & 199 & - & - & - & - & - \\
\hline & 2 & 184 & 186 & 188 & 190 & 192 & 194 & 196 & 198 & - & - & - & - & - & - \\
\hline \multirow[t]{2}{*}{11} & 1 & 200 & 202 & 204 & 206 & 208 & 210 & 212 & - & - & - & - & - & - & - \\
\hline & 2 & 201 & 203 & 205 & 207 & 209 & 211 & 213 & - & - & - & - & - & - & - \\
\hline \multirow[t]{2}{*}{12} & 1 & 214 & 216 & 218 & 220 & 222 & 224 & 226 & - & - & - & - & - & - & - \\
\hline & 2 & 215 & 217 & 219 & 221 & 223 & 225 & - & - & - & - & - & - & - & - \\
\hline \multirow[t]{2}{*}{13} & 1 & 227 & 229 & 231 & 233 & 235 & 237 & 239 & 241 & - & - & - & - & - & - \\
\hline & 2 & 228 & 230 & 232 & 234 & 236 & 238 & 240 & - & - & - & - & - & - & - \\
\hline \multirow[t]{2}{*}{14} & 1 & 242 & 244 & 246 & 248 & 250 & 252 & 254 & - & - & - & - & - & - & - \\
\hline & 2 & 243 & 245 & 247 & 249 & 251 & 253 & - & - & - & - & - & - & - & - \\
\hline
\end{tabular}

- All containers have standard length of 20 feet (one TEU).

- Loader will release containers if and only if there is a shuttle ready at the handling position.

- All input parameters in the simulation are given by the project manager.

The initial interface looks like as shown in Figure 7, where all necessary inputs need to be filled before further computation. User can choose type of input (from an Excel file or manually set), decide the time parameters such as time at change stations, loadingunloading time, arriving time and leaving time (time for shuttles coming in and out of the terminal), decide the velocity for shuttles and trucks, as well as number of loaders and shuttles at each terminal. Finally, user can set the speed of animation to boost up the display speed. All parameters will then be saved with the "Setup Parameter" button.

Next, the computation progress starts after clicking the "Process" button. The task scheduling and task as- 


\begin{tabular}{|c|c|c|c|c|c|c|c|c|c|c|c|c|c|c|c|}
\hline \multirow{2}{*}{$\begin{array}{l}\text { Ter } \\
1\end{array}$} & \multirow{2}{*}{$\begin{array}{l}\text { Loader } \\
1\end{array}$} & \multicolumn{14}{|c|}{ Task ID } \\
\hline & & 1 & 3 & 5 & 13 & 15 & 7 & 17 & 9 & 19 & 11 & 21 & 23 & 25 & - \\
\hline & 2 & 2 & 4 & 6 & 12 & 14 & 16 & 8 & 18 & 10 & 20 & 22 & 24 & - & - \\
\hline \multirow[t]{2}{*}{2} & 1 & 26 & 28 & 32 & 34 & 30 & 36 & 38 & - & - & - & - & - & - & - \\
\hline & 2 & 27 & 31 & 29 & 33 & 35 & 37 & - & - & - & - & - & - & - & - \\
\hline \multirow[t]{2}{*}{3} & 1 & 41 & 39 & 43 & 45 & 47 & 49 & 51 & - & - & - & - & - & - & - \\
\hline & 2 & 40 & 42 & 44 & 46 & 48 & 50 & - & - & - & - & - & - & - & - \\
\hline \multirow[t]{2}{*}{4} & 1 & 56 & 58 & 54 & 60 & 62 & 52 & 64 & 66 & 70 & 68 & 72 & 74 & 76 & 78 \\
\hline & 2 & 57 & 59 & 55 & 61 & 63 & 53 & 65 & 67 & 69 & 71 & 73 & 75 & 77 & - \\
\hline \multirow[t]{2}{*}{5} & 1 & 87 & 89 & 85 & 83 & 93 & 81 & 91 & 79 & 95 & 97 & 99 & 101 & 103 & - \\
\hline & 2 & 88 & 90 & 86 & 84 & 94 & 82 & 92 & 80 & 96 & 98 & 100 & 102 & 104 & - \\
\hline \multirow[t]{2}{*}{6} & 1 & 111 & 115 & 109 & 113 & 117 & 107 & 119 & 105 & 121 & 123 & 125 & - & - & - \\
\hline & 2 & 112 & 110 & 114 & 108 & 116 & 118 & 106 & 120 & 122 & 124 & - & - & - & - \\
\hline \multirow[t]{2}{*}{7} & 1 & 132 & 134 & 136 & 126 & 130 & 138 & 128 & 140 & 142 & 144 & - & - & - & - \\
\hline & 2 & 135 & 131 & 133 & 137 & 127 & 129 & 139 & 141 & 143 & 145 & - & - & - & - \\
\hline \multirow[t]{2}{*}{8} & 1 & 146 & 148 & 150 & 156 & 158 & 160 & 154 & 152 & 162 & 164 & - & - & - & - \\
\hline & 2 & 147 & 149 & 155 & 157 & 159 & 161 & 151 & 153 & 163 & 165 & - & - & - & - \\
\hline \multirow[t]{2}{*}{9} & 1 & 174 & 166 & 176 & 178 & 168 & 180 & 172 & 170 & 182 & - & - & - & - & - \\
\hline & 2 & 175 & 167 & 177 & 179 & 169 & 173 & 171 & 181 & - & - & - & - & - & - \\
\hline \multirow[t]{2}{*}{10} & 1 & 191 & 193 & 195 & 183 & 197 & 185 & 189 & 199 & 187 & - & - & - & - & - \\
\hline & 2 & 192 & 194 & 184 & 196 & 186 & 190 & 188 & 198 & - & - & - & - & - & - \\
\hline \multirow[t]{2}{*}{11} & 1 & 208 & 210 & 200 & 212 & 202 & 206 & 204 & - & - & - & - & - & - & - \\
\hline & 2 & 211 & 209 & 201 & 213 & 207 & 203 & 205 & - & - & - & - & - & - & - \\
\hline \multirow[t]{2}{*}{12} & 1 & 224 & 222 & 226 & 214 & 216 & 220 & 218 & - & - & - & - & - & - & - \\
\hline & 2 & 223 & 221 & 225 & 215 & 217 & 219 & - & - & - & - & - & - & - & - \\
\hline \multirow[t]{2}{*}{13} & 1 & 241 & 239 & 237 & 235 & 227 & 229 & 233 & 231 & - & - & - & - & - & - \\
\hline & 2 & 240 & 238 & 236 & 234 & 228 & 230 & 232 & - & - & - & - & - & - & - \\
\hline \multirow[t]{2}{*}{14} & 1 & 254 & 252 & 250 & 242 & 244 & 248 & 246 & - & - & - & - & - & - & - \\
\hline & 2 & 253 & 251 & 249 & 243 & 245 & 247 & - & - & - & - & - & - & - & - \\
\hline
\end{tabular}

signing process will be done based on the overall layout (as shown in Figure 5) and the given allocation of shuttles from the input step. When finished, user can view the result with the buttons below. In this paper, since we mainly focus on the overall efficiency of the system, we will only display the efficiency of two transportation system (traditional and new system) to make the comparison, as illustrated in Figure 8. From the chart, it is clear that new transportation system has increased the efficiency remarkably, expressed through the reduced time taken in handling all given tasks. The monorail system also satisfies the threshold defined by the project manager.

Moreover, significant evaluation points of the system, such as the total working time, total moving distance of all shuttles and delay of tasks are also recorded as shown in Table 4 and Table 5. Those tables present the records after 10 trials as shown in Figure 7, where Table 4 demonstrates results with random schedule (unarranged schedule) and Table 5 shows results in 
Table 4: Result with unarranged schedule

\begin{tabular}{|c|c|c|c|c|c|c|c|}
\hline Simulation & Average & Total & Average & Total Moving & Minimum & Maximum & Average \\
\hline Time & Working & Working & Moving & \multirow[t]{2}{*}{ Distance } & Delay & Delay & Delay \\
\hline & Time & Time & \multicolumn{2}{|l|}{ Distance } & & & \\
\hline $1075.50 \mathrm{~s}$ & $392.92 \mathrm{~s}$ & $97443.25 \mathrm{~s}$ & $8857.17 \mathrm{~m}$ & $2.20 \mathrm{E}+06 \mathrm{~m}$ & $0.00 \mathrm{~s}$ & $207.00 \mathrm{~s}$ & $12.05 \mathrm{~s}$ \\
\hline $1259.25 \mathrm{~s}$ & $388.35 \mathrm{~s}$ & $96309.75 \mathrm{~s}$ & $8751.22 \mathrm{~m}$ & $2.17 \mathrm{E}+06 \mathrm{~m}$ & $0.00 \mathrm{~s}$ & $203.25 \mathrm{~s}$ & $7.58 \mathrm{~s}$ \\
\hline $1123.75 \mathrm{~s}$ & $391.59 \mathrm{~s}$ & $97114.50 \mathrm{~s}$ & $8824.36 \mathrm{~m}$ & $2.19 \mathrm{E}+06 \mathrm{~m}$ & $0.00 \mathrm{~s}$ & $207.25 \mathrm{~s}$ & $10.75 \mathrm{~s}$ \\
\hline $1266.50 \mathrm{~s}$ & $390.99 \mathrm{~s}$ & $96965.50 \mathrm{~s}$ & $8808.42 \mathrm{~m}$ & $2.18 \mathrm{E}+06 \mathrm{~m}$ & $0.00 \mathrm{~s}$ & $207.25 \mathrm{~s}$ & $10.16 \mathrm{~s}$ \\
\hline $1068.00 \mathrm{~s}$ & $391.48 \mathrm{~s}$ & $97086.75 \mathrm{~s}$ & $8822.76 \mathrm{~m}$ & $2.19 \mathrm{E}+06 \mathrm{~m}$ & $0.00 \mathrm{~s}$ & $236.75 \mathrm{~s}$ & $10.64 \mathrm{~s}$ \\
\hline $1167.00 \mathrm{~s}$ & $391.21 \mathrm{~s}$ & $97020.00 \mathrm{~s}$ & $8816.62 \mathrm{~m}$ & $2.19 \mathrm{E}+06 \mathrm{~m}$ & $0.00 \mathrm{~s}$ & $303.75 \mathrm{~s}$ & $10.38 \mathrm{~s}$ \\
\hline $1253.25 \mathrm{~s}$ & $392.57 \mathrm{~s}$ & $97357.50 \mathrm{~s}$ & $8849.10 \mathrm{~m}$ & $2.19 \mathrm{E}+06 \mathrm{~m}$ & $0.00 \mathrm{~s}$ & $244.00 \mathrm{~s}$ & $11.71 \mathrm{~s}$ \\
\hline $1174.50 \mathrm{~s}$ & $393.96 \mathrm{~s}$ & $97702.00 \mathrm{~s}$ & $8878.35 \mathrm{~m}$ & $2.20 \mathrm{E}+06 \mathrm{~m}$ & $0.00 \mathrm{~s}$ & $256.50 \mathrm{~s}$ & $13.06 \mathrm{~s}$ \\
\hline $1107.00 \mathrm{~s}$ & $392.27 \mathrm{~s}$ & $97282.00 \mathrm{~s}$ & $8843.17 \mathrm{~m}$ & $2.19 \mathrm{E}+06 \mathrm{~m}$ & $0.00 \mathrm{~s}$ & $256.50 \mathrm{~s}$ & $11.41 \mathrm{~s}$ \\
\hline $1260.75 \mathrm{~s}$ & $389.39 \mathrm{~s}$ & $96568.75 \mathrm{~s}$ & $8774.63 \mathrm{~m}$ & \multirow{2}{*}{$\begin{array}{l}2.18 \mathrm{E}+06 \mathrm{~m} \\
\text { ge Value }\end{array}$} & \multirow[t]{2}{*}{$0.00 \mathrm{~s}$} & \multirow[t]{2}{*}{$203.25 \mathrm{~s}$} & \multirow[t]{2}{*}{$8.60 \mathrm{~s}$} \\
\hline \multicolumn{4}{|c|}{ Average Value } & & & & \\
\hline $1175.55 \mathrm{~s}$ & $391.47 \mathrm{~s}$ & $97085.00 \mathrm{~s}$ & $8822.58 \mathrm{~m}$ & $2.19 \mathrm{E}+06 \mathrm{~m}$ & $0.00 \mathrm{~s}$ & $232.55 \mathrm{~s}$ & $10.63 \mathrm{~s}$ \\
\hline
\end{tabular}

Table 5: Result with arranged schedule using Greedy Algorithm

\begin{tabular}{|c|c|c|c|c|c|c|c|}
\hline $\begin{array}{l}\text { Simulation } \\
\text { Time }\end{array}$ & $\begin{array}{l}\text { Average } \\
\text { Working } \\
\text { Time }\end{array}$ & $\begin{array}{l}\text { Total } \\
\text { Working } \\
\text { Time }\end{array}$ & $\begin{array}{l}\text { Average Mov- } \\
\text { ing Distance }\end{array}$ & $\begin{array}{l}\text { Total Moving } \\
\text { Distance }\end{array}$ & $\begin{array}{l}\text { Minimum } \\
\text { Delay }\end{array}$ & $\begin{array}{l}\text { Maximum } \\
\text { Delay }\end{array}$ & $\begin{array}{l}\text { Average } \\
\text { Delay }\end{array}$ \\
\hline $1161.00 \mathrm{~s}$ & $383.41 \mathrm{~s}$ & $95086.00 \mathrm{~s}$ & $8638.78 \mathrm{~m}$ & $2.14 \mathrm{E}+06 \mathrm{~m}$ & $0.00 \mathrm{~s}$ & $203.25 \mathrm{~s}$ & $2.76 \mathrm{~s}$ \\
\hline $1161.00 \mathrm{~s}$ & $383.41 \mathrm{~s}$ & $95086.00 \mathrm{~s}$ & $8638.78 \mathrm{~m}$ & $2.14 \mathrm{E}+06 \mathrm{~m}$ & $0.00 \mathrm{~s}$ & $203.25 \mathrm{~s}$ & $2.76 \mathrm{~s}$ \\
\hline $1161.00 \mathrm{~s}$ & $383.41 \mathrm{~s}$ & $95086.00 \mathrm{~s}$ & $8638.78 \mathrm{~m}$ & $2.14 \mathrm{E}+06 \mathrm{~m}$ & $0.00 \mathrm{~s}$ & $203.25 \mathrm{~s}$ & $2.76 \mathrm{~s}$ \\
\hline $1161.00 \mathrm{~s}$ & $383.41 \mathrm{~s}$ & $95086.00 \mathrm{~s}$ & $8638.78 \mathrm{~m}$ & $2.14 \mathrm{E}+06 \mathrm{~m}$ & $0.00 \mathrm{~s}$ & $203.25 \mathrm{~s}$ & $2.76 \mathrm{~s}$ \\
\hline $1161.00 \mathrm{~s}$ & $383.41 \mathrm{~s}$ & $95086.00 \mathrm{~s}$ & $8638.78 \mathrm{~m}$ & $2.14 \mathrm{E}+06 \mathrm{~m}$ & $0.00 \mathrm{~s}$ & $203.25 \mathrm{~s}$ & $2.76 \mathrm{~s}$ \\
\hline $1161.00 \mathrm{~s}$ & $383.41 \mathrm{~s}$ & $95086.00 \mathrm{~s}$ & $8638.78 \mathrm{~m}$ & $2.14 \mathrm{E}+06 \mathrm{~m}$ & $0.00 \mathrm{~s}$ & $203.25 \mathrm{~s}$ & $2.76 \mathrm{~s}$ \\
\hline $1161.00 \mathrm{~s}$ & $383.41 \mathrm{~s}$ & $95086.00 \mathrm{~s}$ & $8638.78 \mathrm{~m}$ & $2.14 \mathrm{E}+06 \mathrm{~m}$ & $0.00 \mathrm{~s}$ & $203.25 \mathrm{~s}$ & $2.76 \mathrm{~s}$ \\
\hline $1161.00 \mathrm{~s}$ & $383.41 \mathrm{~s}$ & $95086.00 \mathrm{~s}$ & $8638.78 \mathrm{~m}$ & $2.14 \mathrm{E}+06 \mathrm{~m}$ & $0.00 \mathrm{~s}$ & $203.25 \mathrm{~s}$ & $2.76 \mathrm{~s}$ \\
\hline $1161.00 \mathrm{~s}$ & $383.41 \mathrm{~s}$ & $95086.00 \mathrm{~s}$ & $8638.78 \mathrm{~m}$ & $2.14 \mathrm{E}+06 \mathrm{~m}$ & $0.00 \mathrm{~s}$ & $203.25 \mathrm{~s}$ & $2.76 \mathrm{~s}$ \\
\hline $1161.00 \mathrm{~s}$ & $383.41 \mathrm{~s}$ & $95086.00 \mathrm{~s}$ & $8638.78 \mathrm{~m}$ & $2.14 \mathrm{E}+06 \mathrm{~m}$ & $0.00 \mathrm{~s}$ & $203.25 \mathrm{~s}$ & $2.76 \mathrm{~s}$ \\
\hline \multicolumn{8}{|c|}{ Average Value } \\
\hline $1161.00 \mathrm{~s}$ & $383.41 \mathrm{~s}$ & $95086.00 \mathrm{~s}$ & $8638.78 \mathrm{~m}$ & $2.14 \mathrm{E}+06 \mathrm{~m}$ & $0.00 \mathrm{~s}$ & $203.25 \mathrm{~s}$ & $2.76 \mathrm{~s}$ \\
\hline
\end{tabular}




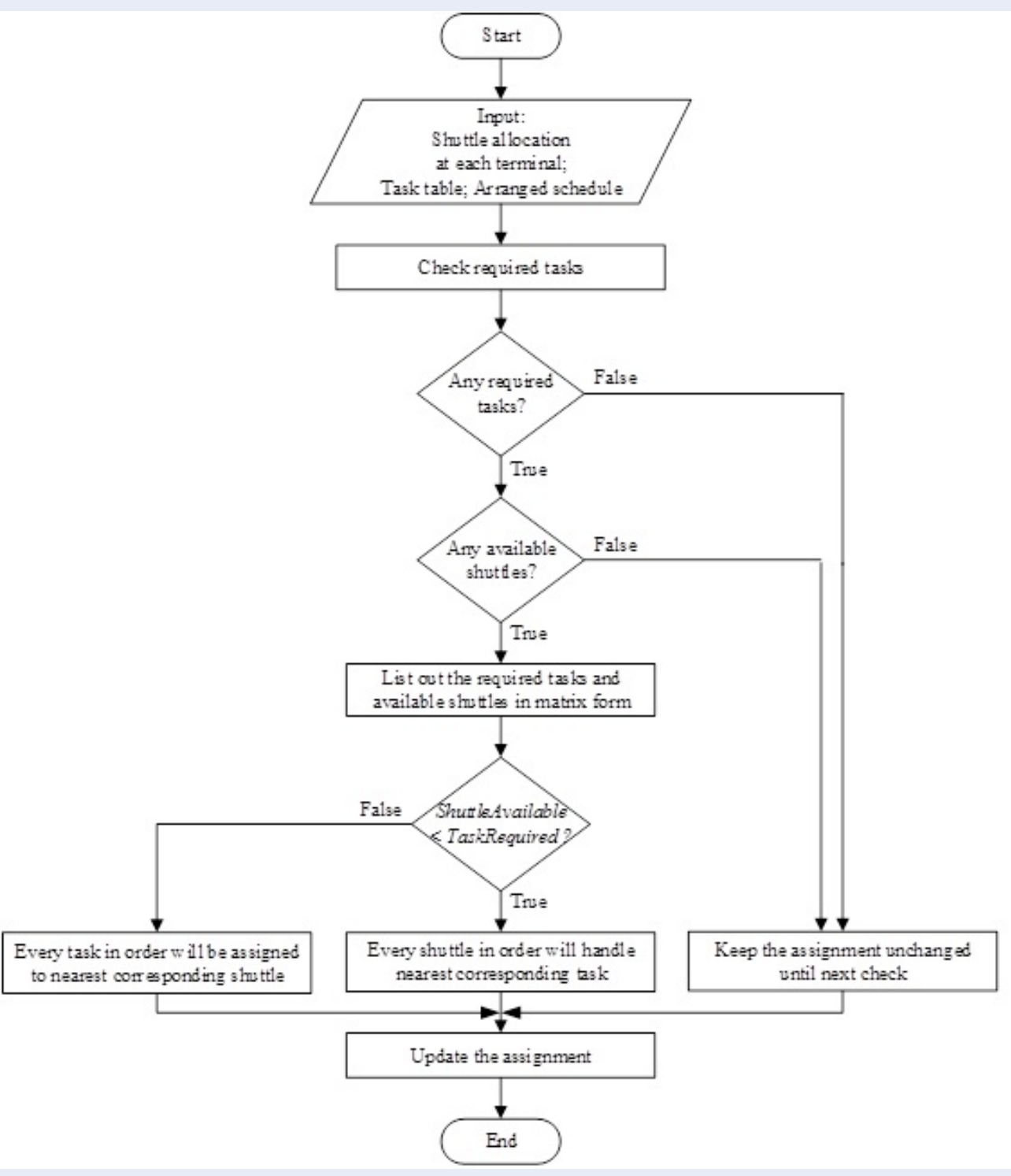

Figure 6: Flowchart for task assigning procedure

case of arranged schedule (applying task scheduling). Final results from Table 4 and Table 5 indicate that arranged schedule reduces travel distance for about $2 \%$ and over 40 kilometres in total (46.88 kilometres). The average delay also drops dramatically from $10.63 \mathrm{~s}$ to 2.76 s (about 280\%). These critical points reveal huge advantages of a well-arranged schedule in logistics activities because they can save large amount of operational expenses and make remarkable benefits for the managers.

\section{ACHIEVED RESULTS}

As shown in Figure 8, it is obviously that the new monorail system has the finishing time much better than traditional transportation system (using trucks) within a same workload. The main reason is that new system has lower loading time and gapping time (time between each transfer), as well as higher moving speed. Basically, a truck can only move with speed of $40-50 \mathrm{~km} / \mathrm{h}$ and has to deal with traffic problems, while a shuttle is manufactured to operate at 80-100 $\mathrm{km} / \mathrm{h}$ without traffic congestion. Loading time for shuttles is about 10 seconds with loader, while it takes about 1 minutes to pick up a container for trucks. All of those make the new system more efficient for intense workload at Busan Port.

In addition, based on the simulation implemented in Section 3, it is clear that the better schedule achieved 


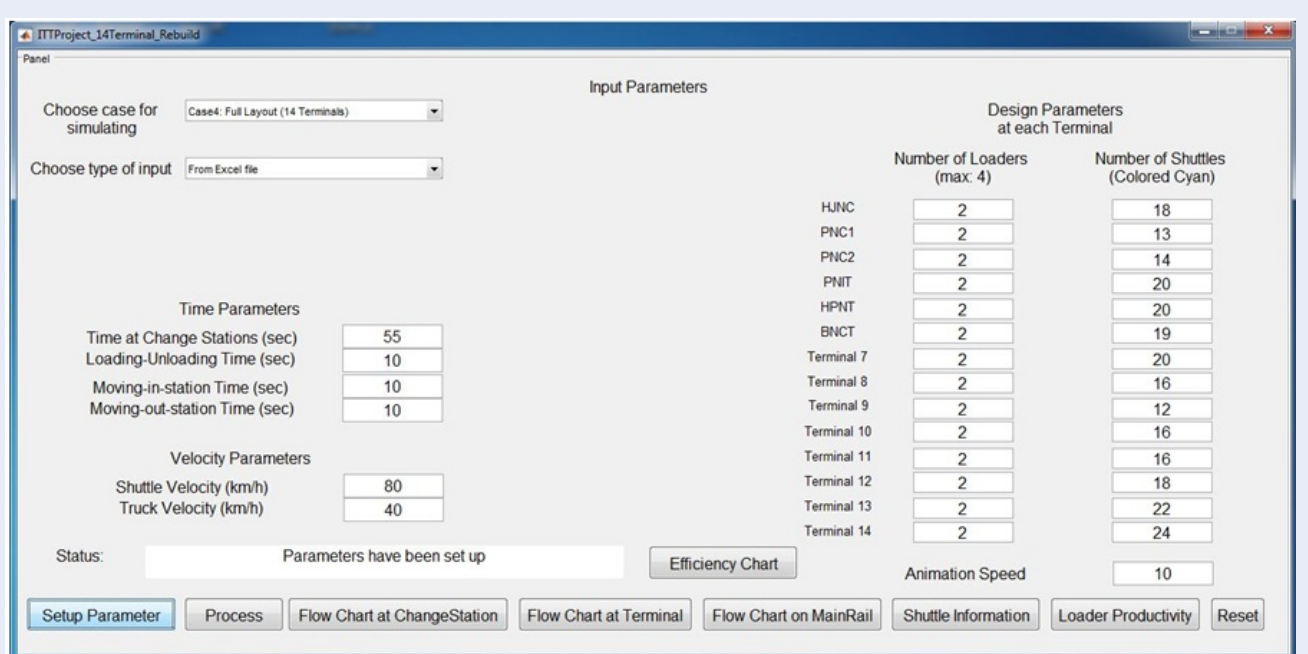

Figure 7: Interface's appearance after filling inputs

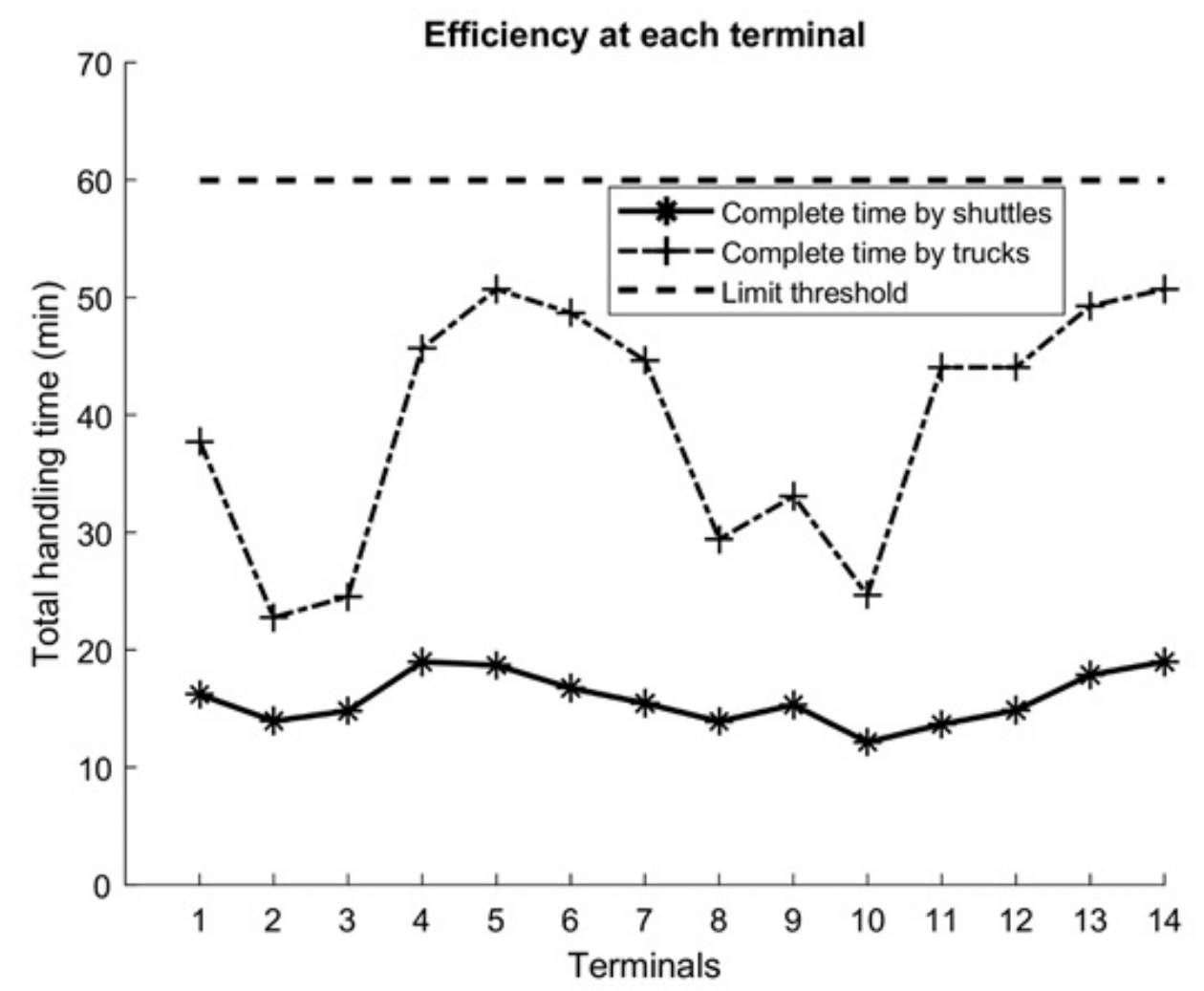

Figure 8: Time taken when applying traditional and new transportation system 
from Greedy Algorithm gives better result for the whole process. Table 4 and Table 5 have shown that all critical points (simulation time, total working time, total moving distance, average moving distance, maximum delay and average delay) are improved a lot. All time parameters are optimized as desired and they will make great impact to the overall efficiency. Note that the simulation is done based on a workload of about 250 containers as a study case. In practice, the real demand could be 100 times greater (about 25000 - 30000 containers per day). However, the optimization principle still remains unchanged, and it is expected that the travel distance and the average delay would also decrease for $2 \%$ and $280 \%$, respectively (according to Section 3).

\section{DISCUSSION}

According to the achieved results as in Section 4, it is apparent that a well-organized plan for tasks will grant more effectiveness in comparison to randomized plan. Nonetheless, in real world, a complete system would comprise numerous parameters and criteria to be considered, making the optimization problem more complicated and the solution sometimes would not fit for all cases. Since this is a combinatorial problem, there might be a lot of combination that can lead to a same outcome, which means there has to be a lot of time-taking computation, resulting in slow response for real-time activities. For technical aspects, it is reasonable to be approved with a non-global solution, where only the dominant criteria are satisfied and the trivial disadvantages can be ignored.

In our problem, the dominant criteria is chosen as the total moving distance of working shuttles and the average delay for all tasks, and the solution found from Greedy Algorithm supposes to fulfill the optimization goal. However, currently it is not possible to prove the uniqueness of the solution, and there might be other better solutions for this problem. In this research, our final goal is to reveal a good solution that can reduce the total moving distance and the average delay, and the achieved results from Section 4 seem to meet the requirements.

\section{CONCLUSION}

To sum up, this research has proposed a solution for optimization in scheduling and assigning in the new ITT project being built at Busan Port in South Korea, which are both essential in reducing operational cost. Effectiveness of the optimization procedures has been proved in our study case and it is expected to also ensure the precision in reality, where the workload could be thousands times greater.
In addition, it is emphasized that the obtained result mainly focuses on general behaviors of the new ITT System in comparison with traditional transport mode and does not give deeper analysis to the dynamic model of the system, where specification of devices and equipment would be further evaluated such as weight and dimension of shuttles and containers. It is due to the fact that the project is still at the general analysis stage, where all input parameters are not fixed yet and the project managers are still considering. Real model for loaders and shuttles have not been built yet, as well as the layout also has not been constructed completely, so dynamic properties of the system are temporarily ignored. These factors are obviously important; however, they would be considered at further analysis stages of the project.

At the moment, all parameters in the simulation are proposed by the project managers, as the main objective of this stage is to evaluate the possibility of the system. The simulation model is still not enough constraints, such as velocity limits or load distributions. In later stages where the system is modelled more completely, these constraints would be considered in order to fulfill the research.

\section{ABBREVIATIONS}

ITT: Inter-Terminal Transport

TEU: Twenty-feet Equivalent Unit

MATLAB: MAtrix LABoratory (a program from MathWorks)

\section{CONFLICT OF INTEREST}

The authors wish to confirm that there are no know conflicts of interest associated with this publication and there has been no significant financial support for this work that could have influenced its outcome.

\section{AUTHORS' CONTRIBUTION}

All authors conceived of the study and participated in its research and coordination and helped to draft the manuscript. The authors read and approved the final manuscript.

\section{REFERENCES}

1. Pieriegud J. Analysis of the potential of the development of rail container transport market in Poland. Report of European Commission. 2019;.

2. Davies P. Container Terminal Reservation Systems Design and Performance. METRANS International Urban Freight Conference, Long Beach CA. 2013;

3. Yang W, Song H. Railway Container Terminal Station Layout and Operation Plan of Container Trucks. LISS 2014, Springer, Berlin, Heidelberg. 2014;Available from: https://doi.org/10. 1007/978-3-662-43871-8_54. 
4. Lee BK, et al. A Simulation Study for Designing a Rail Terminal in a Container Port. Proceedings of the 2006 Winter Simulation Conference, Monterey, USA, 2006;PMID: 16739990. Available from: https://doi.org/10.1109/WSC.2006.323239.

5. Heilig L. Stefan Vo $\beta$ : Inter-terminal transportation: an annotated bibliography and research agenda. Flexible Services and Manufacturing Journal. 2017;29(1):35-63. Available from: https://doi.org/10.1007/s10696-016-9237-7.

6. Rodrigue JP. Transportation Modes. in The Geography of Transport Systems, 4th Edition, London: Taylor \& Francis Ltd. 2017;

7. Duinkerken MB, et al. Comparing transportation systems for inter-terminal transport at the Maasvlakte container terminals. OR Spectrum. 2006;28(4):469-493. Available from: https: //doi.org/10.1007/s00291-006-0056-1.

8. World Shipping Council: Top 50 world container ports;Available from: http://www.worldshipping.org/aboutthe-industry/global-trade/top-50-world-container-ports.

9. Negenborn R. Project: Innovative Concepts for Inter Terminal Transport on Maasvlakte 1 and 2 at the Port of Rotterdam. TUDelft, Rotterdam. 2013;Available from: http://www. negenborn.net/rudy/projects_itt.html.

10. Duinkerken MB, Negenborn RR. Inter-terminal transport on Maasvlakte 1 and 2 in 2030: Towards a multidisciplinary and innovative approach on future inter-terminal transport options. TUDelft, Rotterdam. 2014; .

11. Heilig L, Voss S. Inter-terminal transportation: an annotated bibliography and research agenda. Flexible Services and Manufacturing Journal. 2017;29(1):35-63. Available from: https: //doi.org/10.1007/s10696-016-9237-7.
12. Qiu L, et al. Scheduling and routing algorithms for AGVs: A survey. International Journal of Production Research. 2002;40(3):745-760. Available from: https://doi.org/10.1080/ 00207540110091712

13. Ng WC. Crane scheduling in container yards with intercrane interference. European Journal of Operational Research. 2005;164(1):64-78. Available from: https://doi.org/10.1016/j. ejor.2003.11.025.

14. Hwan-Seong K. Busan Port New Port ITT Infrastructure Project. Project document, Korea Maritime and Ocean University. 2019;.

15. Hoos HH, Stützle T. Travelling Salesman Problem. Stochastic Local Search. 2005;

16. Greco F. Travelling Salesman Problem. I-Tech Education and Publishing KG, Vienna, Austria. 2008;Available from: https:/ doi.org/10.5772/66.

17. Klarreich E. Computer Scientist Find New Shortcuts for Infamous Travelling Salesman Problem. 2013;Available from: https://www.wired.com/2013/01/traveling-salesmanproblem/.

18. Vince A. A framework for the greedy algorithm. Discrete Applied Mathematics. 2002;121:247-260. Available from: https //doi.org/10.1016/S0166-218X(01)00362-6.

19. Bang-Jensen J, et al. When the greedy algorithm fails. Discrete Optimization. 2004;1(2):121-127. Available from: https://doi. org/10.1016/j.disopt.2004.03.007.

20. Bendall G, Margot F. Greedy-type resistance of combinatoria problems. Discrete Optimization. 2006;3(4):288-298. Available from: https://doi.org/10.1016/j.disopt.2006.03.001. 


\title{
Tối ưu hóa trong giải quyết tác vụ trong hệ thống vận chuyển monorail ở cảng Busan
}

\author{
Lê Ngọc Bảo Long ${ }^{1}$, Nguyễn Duy Anh ${ }^{1,{ }^{*}}$, Kim Hwan-Seong ${ }^{2}$
}

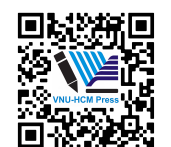

Use your smartphone to scan this QR code and download this article

${ }^{1}$ Truờng Đại học Bách khoa, ĐHQG-HCM, Việt Nam

${ }^{2}$ Trường Đại học Hàng hải Hàn Quốc, Busan, Hàn Quốc.

\section{Liên hệ}

Nguyễn Duy Anh, Trường Đại học Bách khoa, ĐHQG-HCM, Việt Nam

Email: duyanhnguyen@hcmut.edu.vn

Lịch sử

• Ngày nhận: 08-06-2020

- Ngày chấp nhận: 22-03-2021

- Ngày đăng: 31-03-2021

DOI : $10.32508 /$ stdjet.v4i1.746

\section{Check for updates}

\section{Bản quyền}

๑ ĐHQG Tp.HCM. Đây là bài báo công bố mở được phát hành theo các điều khoản của the Creative Commons Attribution 4.0 International license.

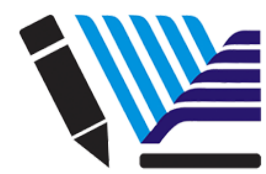

VNU-HCM Press

\section{TÓM TẮT}

Bài báo này trình bày một giải pháp tối ưu cho quá trình xử lý tác vụ ở cảng container Busan tại Hàn Quốc. Ở thời điểm hiện tại, một hệ thống vận chuyển monorail đang được xây dựng và dự kiến đưa vào sử dụng vào năm 2045. Đây là một dự án có sự tham gia của chính phủ Hàn Quốc nhằm mục đích nâng cao hiệu suất sử dụng trong cảng Busan - một trong những cảng container lớn nhất thế giới. Trong hệ thống này, phương tiên vận chuyển là các shuttle (hình dạng con thoi) chạy dọc theo đường ray chỉ theo một chiều, thông qua các trạm đặc biệt gọi là trạm chuyển đổi tương tư như hê thống chuyển làn trên đường ray xe lửa để đến các tram mong muốn nơi có các thiết bị gắp đợi để xử lý. Toàn bộ quá trình hoạt động có thể được chia thành 2 khâu chính: lên kế hoạch cho tác vụ và phân bổ tác vụ. Tất cả các container trước tiên phải được lên kế hoạch hợp lý ở từng trạm dựa trên bảng tác vụ, và sau đó phải được phân bổ một cách tối ưu đến các shuttle để đạt được kết quả tốt nhất. Bài báo chủ yếu tập trung vào bài toán tối ưu thời gian trong việc lên kế hoạch và phân bổ tác vụ - những vấn đề tối ưu quan trọng nhằm mục đích giảm thời gian vận hành và độ trễ trung bình của hệ thống. Để giải quyết vấn để này, một giải thuật heuristic gọi là giải thuật Tham Lam được tiến hành nhằm sắp xếp tác vụ được giao theo một trình tự hợp lý và phân bổ những tác vụ đã sắp xếp cho shuttle phù hợp, bằng cách tính toán thời gian di chuyển giữa các trạm và thời gian để shuttle tiếp cận loader. Tất cả kết quả quan trọng khi có và không có giải thuật Tham Lam được ghi lại và so sánh để chỉ ra sự khác biệt giữa các quy trình, bao gồm tổng thời gian hoạt động, tổng quãng đường di chuyển, quãng đường di chuyển trung bình và độ trễ trung bình của toàn bộ quá trình. Tất cả mô phỏng được tiến hành trên phần mềm MATLAB, với các số liệu đánh giá cuối cùng chỉ ra các tiêu chí quan trọng và làm nổi bật ưu điểm của hệ thống mới, cũng như lợi ích của các phương pháp tối ưu đã áp dụng.

Từ khoá: Vận chuyển liên trạm, Hệ thống monorail, Lên kế hoạch, Phân bổ, Cảng Busan, Thuật toán Tham lam
Trích dẫn bài báo này: Long $L \mathrm{~N} B, A$ h $N \mathrm{D}$, Hwan-Seong $K$. Tối ưu hóa trong giải quyết tác vụ trong hệ thống vận chuyển monorail ở cảng Busan. Sci. Tech. Dev. J. - Eng. Tech.; 4(1):759-771. 